\title{
KAMPUNG TEMATIK SEBAGAI ELEMEN PRIMER KEGIATAN WISATA PERKOTAAN DI SURAKARTA
}

\author{
Shilvia Dwi Cahyani', Winny Astuti ${ }^{1}$, Rufia Andisetyana Putri ${ }^{1}$ \\ ${ }^{1}$ Program Studi Perencanaan Wilayah dan Kota, Fakultas Teknik, Universitas Sebelas Maret
}

\begin{abstract}
Abstrak
Urban tourism merupakan daya tarik wisata yang berlokasi di kota dan perkotaan sehingga menarik wisatawan dari daerah lain untuk berkunjung ke kota. Pada tahun 2018, Kota Surakarta mengembangkan sektor pariwisata dalam bentuk Urban Tourism. Urban Tourism diangkat dengan mengembangkan potensi yang dimiliki oleh Kampung di Kota Surakarta, sehingga menghasilkan kampung tematik sebagai atraksi baru dalam pariwisata di Kota Surakarta. Atraksi wisata di dalam konsep urban tourism disebut dengan elemen primer, sehingga kampung tematik berperan sebagai Elemen primer dari program kerja Urban Tourism di Kota Surakarta. Ada 6 Kampung Tematik di Kota Surakarta, yaitu Joho Kampoeng Hepi, Kampung Batik Laweyan, Kampung Blangkon Petrojayan, Kampung Sayur Mojosongo, Kampung Batik Kauman, dan Jayengan Kampoeng Permata. Kampung Tematik sebagai elemen primer urban tourism dijadikan sebagai salah satu pendorong untuk menaikkan jumlah kunjungan wisata ke Kota Surakarta, sehingga muncul pertanyaan penelitian bagaimana kesesuaian Kampung Tematik di Kota Surakarta sebagai elemen primer urban tourism. Dari pertanyaan tersebut menghasilkan tujuan penelitian yaitu untuk mengetahui kesesuaian Kampung Tematik di Kota Surakarta sebagai elemen primer dalam konsep Urban Tourism. Karakteristik yang akan dilihat berdasarkan atraksi wisata berupa kebudayaan, fasilitas pendukung wisata, perubahan sosial ekonomi masyarakat, dan aksesibilitas. Penelitian ini mengunakan metode penelitian kuantitatif dengan pendekatan deduktif, dan melalui teknik analisis skoring. Hasil analisis menunjukkan bahwa besar persentase kesesuaian Kampung Tematik di Kota Surakarta sebagai elemen primer urban tourism adalah sebesar 33\%. Rendahnya persentase kesesuaian dikarenakan beberapa Kampung Tematik belum dapat menyajikan keberagaman atraksi wisata dan fasilitas.
\end{abstract}

Kata kunci: elemen primer urban tourism; kampung tematik; urban tourism

\begin{abstract}
Urban tourism is a tourist attraction located in cities and attracts tourists from other areas to visit the city. In 2018, Surakarta developed the tourism sector in the form of Urban Tourism. Urban Tourism is promoted by creating thematic villages, which is developing the speciality ofKampung to as the central attraction for tourism activities in Surakarta. Tourist attractions in urban tourism concept functions or are named as primary elements of urban tourism, so the thematic villages have a role as the primary element of the Urban Tourism project in Surakarta. There are 6 Thematic Villages in Surakarta, namely Joho Kampoeng Hepi, Kampung Batik Laweyan, Kampung Blangkon Petrojayan, Kampung Sayur Mojosongo, Kampung Batik Kauman, and Jayengan Kampoeng Permata. Thematic Village as a primary element of urban tourism is used as one of the drivers to increase the number of tourist visits to Surakarta. Having said that, the research question is to what extent the thematic village in the city of Surakarta is suitable as the primary element of urban tourism. The characteristics of primary element of ran tourisminvestigated here are based on cultural attractions, tourism support facilities, social-economic change, and accessibility. This study applies quantitative method with scoring analysis techniques. The results of the analysis show that the suitability percentage of Thematic Villages in Surakarta as the primary element of urban tourism is merely $33 \%$. The low percentage of suitability is due to several thematic villages that have not been able to present the diversity of tourist attractions and facilities.
\end{abstract}

Keywords: primary elemen of urban tourism; thematic villages; urban tourism

\section{PENDAHULUAN}

Urban tourism adalah salah satu bentuk pariwisata yang bertempat di kota besar, yang mana pariwisata mungkin penting tetapi bukan sebagai aktivitas utama dari daerah perkotaan tersebut (Inskeep, 1991). Elemen Urban Tourism terbagi menjadi 3 , yaitu elemen primer, elemen sekunder, dan elemen tambahan. Elemen primer merupakan atraksi wisata utama yang dapat 
menarik pengunjung untuk ke kota (Shaw dan Williams dalam Priono, 2012). Menurut Law dalam Garbea (2013) elemen sekunder adalah segala hal yang membuat turis nyaman, sedangkan elemen tambahan dimaksudkan untuk mempermudah pengunjung mengakses elemen primer dan sekunder.

Pada tahun 2018, Kepala Dinas Pariwisata Kota Surakarta bidang destinasi wisata Is Purwaningsih mengatakan bahwa Kota Surakarta saat ini sedang mengalami stagnasi obyek wisata bahkan cenderung memiliki pertumbuhan pariwisata yang lambat (Wicaksono, 2018). Indikasi dari stagnannya obyek wisata adalah menurunnya jumlah kunjungan wisata ke Kota Surakarta, khususnya pada destinasi wisata bersejarah dan budaya seperti Keraton Kasunanan, wayang orang Sriwedari, dan Taman Budaya Surakarta. Untuk mendongkrak jumlah kunjungan wisata ke Kota Surakarta, Pemerintah Kota Surakarta pada tahun 2018 mulai mengembangkan program pariwisata perkotaan atau urban tourism. Urban Tourism atau wisata perkotaan dalam Perda Rencana Induk Pembangunan Kepariwisataan Daerah (RIPPKADA) Kota Surakarta tahun 2016-2026 masuk ke dalam jenis pengembangan dari kategori kegiatan wisata daya tarik wisata hasil buatan manusia.

Daya tarik pengembangan urban tourism di Kota Surakarta adalah berupa Kampung Tematik. Konsep kampung tematik menurut Idziak, Majewski, \& Zmyslony (2015) dalam Tamara \& Rahdriawan (2018) lebih pada menawarkan masyarakat untuk terlibat proaktif, sehingga tidak hanya berbasis masyarakat tetapi juga penciptaan ruang kampung berciri khas yang berkelanjutan oleh masyarakat. Di Kota Surakarta sendiri terdapat 6 Kampung Tematik yang sudah dikembangkan, yaitu Joho Kampoeng Hepi, Kampung Batik Laweyan, Kampung Blangkon Petrojayan, Kampung Sayur Mojosongo, Kampung Batik Kauman, dan Jayengan Kampoeng Permata (Aosgi, 2018).

Kampung Batik Laweyan merupakan kampung tematik yang tertua dan sudah ditetapkan menjadi destinasi wisata. Berdasarkan RIPPKADA Kota Surakarta tahun 2016-2026, Kampung Batik Laweyan termasuk ke dalam Kawasan Strategis Pariwisata Kota Surakarta. Hal ini sejalan dengan beragamnya atraksi wisata di Kampung Batik Laweyan yang beragam seperti adanya event Selawenan dan beberapa bangunan bersejarah ditetapkan sebagai cagar budaya seperti Langgar Merdeka. Beragamnya atraksi wisata mendorong masyarakat untuk menyediakan fasilitas pendukung wisata seperti tempat makan, akomodasi, dan tempat belanja.

Kampung Batik Kauman juga merupakan salah satu kampung tematik yang sudah ditetapkan sebagai destinasi wisata. Berdasarkan RIPPKADA Kota Surakarta tahun 2016-2026, Kampung Batik Kauman merupakan Kawasan Strategis Pariwisata Kota Surakarta yang termasuk ke dalam bagian Destinasi Pariwisata Daerah Karaton Surakarta Hadiningrat. Keberadaan Kampung Batik Kauman berkaitan erat dengan Keraton Kasunanan Surakarta. Banyak bangunan bersejarah di Kampung Batik Kauman yang merupakan peninggalan aktivitas Keraton Kasunanan Surakarta seperti Komplek Masjid Agung dan beberapa langgar. Event Mauludan merupakan contoh lain hubungan antara Keraton Kasunana Surakarta dengan Kampung Batik Kauman. Pada Kampung Batik Kauman juga dilengkapi oleh fasilitas pendukung wisata yang lengkap.

Jayengan Kampoeng Permata merupakan bentuk hubungan antara Keraton Kasunanan Surakarta dengan saudagar asal Martapura (saudagar Banjar). Kemudian pada Jayengan Kampoeng Permata terjadi akulturasi budaya di antara penduduk asli dengan penduduk pendatang (saudagar Banjar). Akulturasi ini tergambar ke dalam event wisata yang terselanggara, yaitu Jarwono (Banjar, Jowo, Cino). Akan tetapi, Jayengan Kampoeng Permata belum memiliki monumen sebagai penanda kawasan, selain sebagai penanda monumen juga dimanfaatkan untuk atraksi wisata. Masyarakat di Jayengan Kampoeng Permata sudah menyediakan fasilitas pendukung wisata.

Kampung Sayur Mojosongo memiliki atraksi wisata berupa budaya masyarakat untuk menanam tanaman sayur organik. Kampung Sayur Mojosongo memiliki event rutin tahunan untuk memperingati hari bumi. Selain itu, anak-anak di Kampung Sayur Mojosongo juga aktif dalam kegiatan seni karawitan. Sayangnya kesenian ini belum didukung dengan adanya fasilitas budaya di kawasan. Masyarakat pada Kampung Sayur Mojosongo belum menyediakan akomodasi untuk wisatawan menginap.

Kampung Blangkon Petrojayan memiliki hubungan langsung dengan Keraton Kasunanan Surakarta, di mana seorang ahli pembuat blangkon Keraton menularkan ilmu membuat blangkon kepada anak dan muridnya yang tinggal di Kampung Blangkon Petrojayan. Sayangnya Kampung Blangkon Petrojayan belum menyelenggarakan event untuk menarik wisatawan dari luar. Selain itu, masyarakat juga belum dapat menyediakan fasilitas pendukung berupa akomodasi untuk wisatawan. 
Joho Kampoeng Hepi merupakan kampung yang membranding diri dengan Kampung Ramah Anak. Di kampung ini banyak terselenggara event-event yang ditujukan untuk edukasi anak, seperti dolanan anak, literasi, kesenian dan lain-lain. Namun, Joho Kampoeng Hepi belum dilengkapi dengan fasilitas budaya sehingga masyarakat menyelenggarakan event di jalan utama kampung. Masyarakat juga belum dapat menyediakan akomodasi untuk wisatawan menginap.

Menurut Ketua Asita DPC Kota Surakarta , kunjungan wisata berbasis Kampung Tematik atau community based on tourism serta keragaman wisata kuliner di Kota Surakarta ternyata sudah mulai tumbuh pesat di Kota Surakarta (Widodo, 2018). Sehingga diharapkan dapat meningkatkan kunjungan wisatawan ke Kota Surakarta. Akan tetapi, ternyata di beberapa Kampung Tematik masih belum tersedia keberagaman atraksi berupa kebudayaan yang sesuai dengan elemen primer dalam urban tourism. Selain itu juga belum tersedia fasilitas pendukung berupa akomodasi yang disediakan oleh masyarakat. Kemudian muncul pertanyaan penelitian, bagaimana kesesuaian Kampung Tematik di Kota Surakarta sebagai elemen primer dalam konsep urban tourism

\section{KAJIAN LITERATUR}

Kajian literatur berisi mengenai teori yang digunakan di dalam penelitian untuk merumuskan variabel. Dalam penelitian yang dilakukan menggunakan teori mengenai urban tourism, elemen primer dalam urban tourism, dan kampung tematik sebagai fokus penelitian.

\subsection{DEFINISI URBAN TOURISM}

Menurut United Nation World Tourism Organization (UNWTO), urban tourism adalah jenis pariwisata yang bertempat di daerah perkotaan dengan kelengkapan karakteristik atributnya di mana bukan berbasis pada sektor agriculture tetapi ekonominya bertumpu pada pemerintahan, pabrik/industri, perdagangan dan jasa, serta menjadi titik nodal dalam transportasi. Menurut Inskeep (1991), urban tourism adalah salah satu bentuk dari pariwisata yang bertempat di kota besar di mana pariwisata mungkin sangat penting tetapi bukan merupakan aktivitas utama dari perkotaan tersebut. Sedangkan menurut Klinger (2006) dalam Widyaiswaratika (2016) urban tourism adalah satu kesatuan daya tarik wisata atau aktivitas yang berlokasi di kota dan perkotaan yang menarik pengunjung dari daerah lain.

\subsection{KOMPONEN URBAN TOURISM}

Secara umum komponen urban tourism terbagi menjadi 3, yaitu elemen primer, elemen sekunder, dan elemen tambahan. Untuk mempermudah dapat dilihat pada Gambar 1.

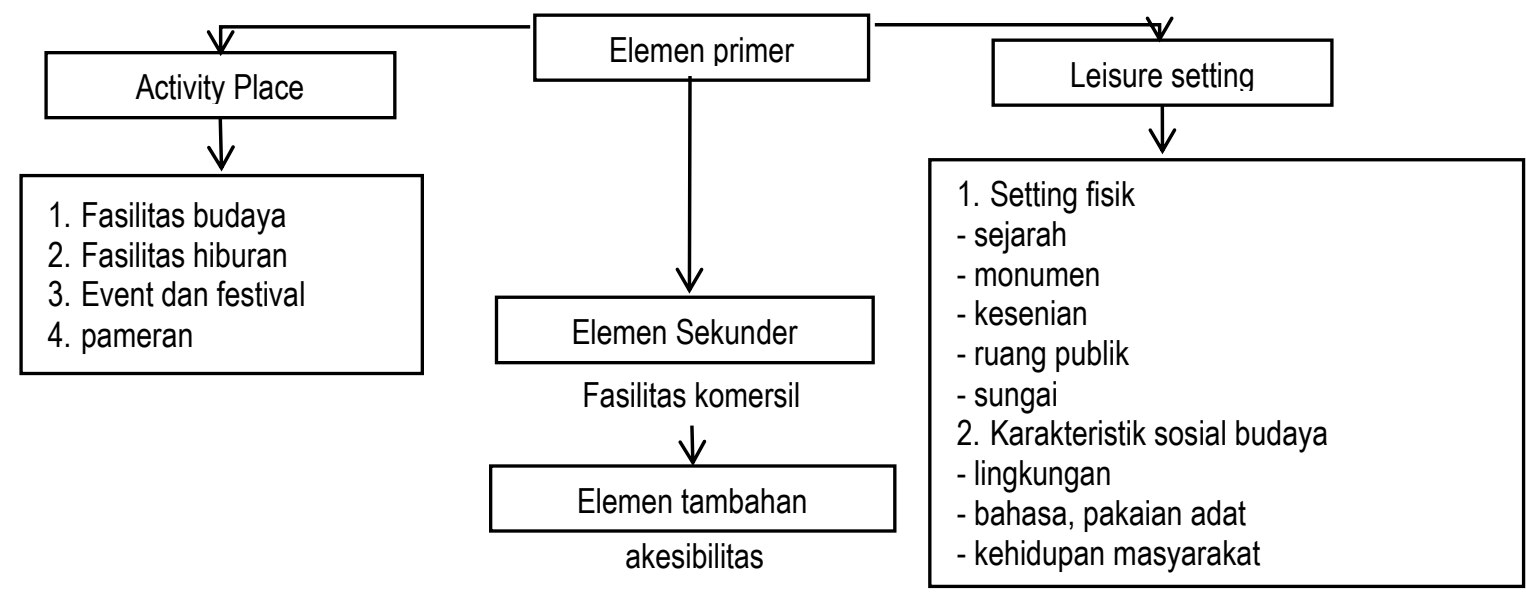

Sumber : Ruetsche (2006), Priono (2012) Law dalam Garbea (2013), Garbea (2013)

Gambar 1. Diagram Komponen Urban Tourism

Dari diagram di atas, dapat diketahui bahwa Kampung Tematik di Kota Surakarta memiliki posisi sebagai Elemen Primer. 


\subsection{ELEMEN PRIMER DALAM URBAN TOURISM}

Elemen primer merupakan atraksi wisata utama yang dapat menarik pengunjung untuk ke kota (Shaw dan Williams dalam Priono, 2012). Menurut Page (2002), elemen primer dalam urban tourism harus membuat nyaman baik pengunjung maupun penduduk secara bersamaan, memiliki pelayanan dan fasilitas yang beragam, membangun atmosfir sosial budaya yang atraktif, dan pada waktu yang sama dapat menciptakan industri baru, sehingga dapat membuka lapangan pekerjaan baru, meningkatkan pendapatan masyarakat, serta meningkatkan standar hidup. Berdasarkan Edwards (2008), mengatakan bahwa kunci elemen primer adalah bahwa atraksi wisata harus dapat menarik pengunjung karena pembangunannya lebih bagus dibandingkan tempat lain, kawasan dengan mudah diakses terutama oleh bandara dan transportasi lain, didukung oleh akomodasi yang memadai. Hal tersebut dapat menarik pasar (pengunjung adalah orang yang berpendidikan, orang dewasa, anak muda) karena menawarkan layanan yang bagus baik transportasi, komunikasi, dan fasilitas yang dibutuhkan pengunjung. Atraksi yang ditawarkan berupa warisan budaya dari kawasan, atau kehidupan di lingkungan tersebut. Selain itu teori yang diperoleh dari Razavi, Barta, \& Amini, (2017) mengemukakan bahwa atraksi wisata utama dalam urban tourism harus memiliki atraksi berupa kebudayaan, kontak langsung antara turis dengan penduduk setempat, merubah perilaku sosial dan pekerjaan, serta pembangunan fasilitas pariwisata.

Dari teori yang dikemukakan oleh Page (2002), Edwards (2008), dan Razavi, Barta, \& Amini, (2017) disandingkan dengan Gambar 1 didapatkan hasil bahwa elemen primer di dalam urban tourism harus memiliki atraksi wisata berupa kebudayaan, tersedia fasilitas pendukung wisata, membawa perubahan sosial ekonomi masyarakat, dan aksesibilitas. Ke empat poin tersebut dijadikan sebagai variabel penelitian, yang kemudian akan dijelaskan pada Tabel 1.

\subsection{KAMPUNG TEMATIK}

Kampung tematik merupakan salah satu contoh yang baik dalam inovasi sosial (Kłoczko-Gajewska, 2014). Berdasarkan Kłoczko-Gajewska (2014) kampung tematik adalah sebuah kampung di mana masyarakatnya memutusukan untuk mengembangkan daerah mereka berdasarkan sebuah gagasan atau topik yang dapat membuat kampung tersebut mudah dikenali dan menjadi salah satu yang terbaik. Menurut Tamara \& Rahdriawan (2018) kampung tematik memiliki tujuan mengatasi kemiskinan terutama permasalahan pemenuhan kebutuhan dasar, mendorong perekonomian lokal dengan menggali potensi-potensi ekonomi kemasyarakatan sebagai stimulus pembangunan wilayah, serta peningkatan kualitas lingkungan rumah tinggal masyarakat. Sedangkan menurut Ujianto, Zahro, \& Maringka (2018), kampung tematik merupakan titik sasaran dari sebagian wilayah kelurahan yang dilakukan perbaikan dengan memperhatikan beberapa hal sebagai berikut:

a) Mengubah lokasi kumuh menjadi tidak kumuh/peningkatan/perbaikan kondisi lingkungan

b) Peningkatan penghijauan wilayah yang intensif

c) Pelibatan partisipasi masyarakat secara aktif .

d) Mengangkat potensi sosial dan ekonomi masyarakat setempat (pemberdayaan)

\section{METODE PENELITIAN}

Di dalam metode penelitian akan dibahas mengenai ruang lingkup, pengumpulan data, metode analisis, dan variabel penelitian.

\subsection{RUANG LINGKUP}

Berdasarkan laman resmi pemerintah Kota Surakarta menyebutkan bahwa ada 6 kampung tematik yang menjadi destinasi wisata di Kota Suralarta (Aosgi, 2018). Enam kampung tematik tersebut (lihat Gambar 2) adalah Joho Kampoeng Hepi, Kampung Batik Laweyan, Kampung Blangkon Petrojayan, Kampung Sayur Mojosongo, Kampung Batik Kauman, dan Jayengan Kampoeng Permata. 


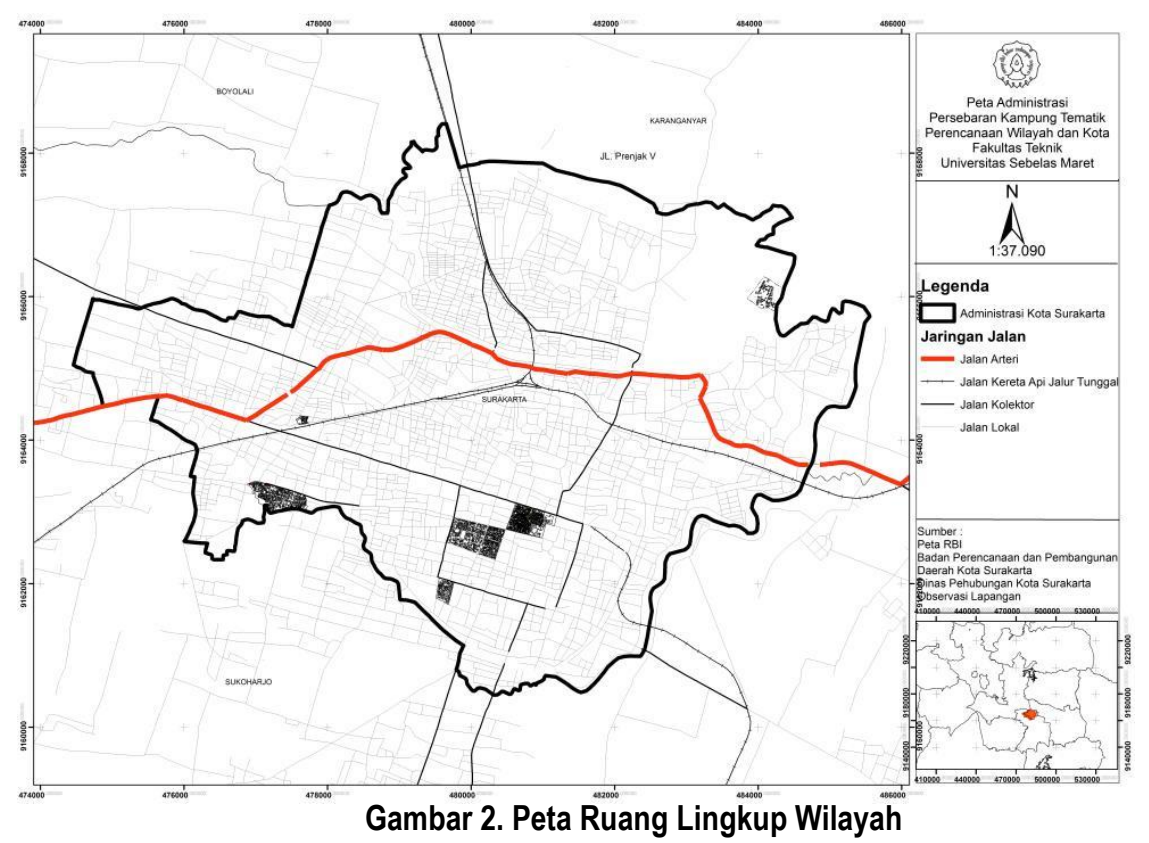

\subsection{TEKNIK PENGUMPULAN DATA}

Data untuk penelitian ini dikumpulan pada tahun 2019. Ada 2 cara yang dilakukan oleh peneliti untuk mengumpulkan data di dalam penelitian ini, yaitu:

\subsubsection{Pengumpulan Data Primer}

Data primer dikumpulkan dengan cara wawancara dengan key person, observasi, serta kuesioner. Wawancara dengan key person berarti peneliti melakukan wawancara dengan responden yang memiliki tingkat kepentingan dan pengaruh yang besar terhadap kampung tematik, sehingga responden dianggap sebagai orang yang penting dan paham terhadap pertanyaan-pertanyaan yang diajukan. Responden yang dipilih adalah ketua kampung tematik yang menjadi fokus dalam penelitian. Wawancara dengan ketua kampung tematik dilakukan untuk mendapatkan data atraksi wisata di kampung tematik. Teknik pengumpulan data observasi dilakukan dengan terjun secara langsung ke lapangan sehingga dapat mengetahui kondisi di lapangan pada lokasi penelitian. Observasi ini ditujukan untuk hal-hal yang bersifat fisik. Pada teknik pengumpulan data ini digunakan untuk memperoleh data terkait fasilitas pendukung wisata di kampung tematik. Kuesioner ditujukan untuk masyarakat yang ada pada kampung tematik. Kuesioner yang akan dilakukan memerlukan responden sejumlah 180 responden, dengan masing-masing kampung tematik membutuhkan 30 responden. Kuesioner digunakan untuk mendapatkan data terkait perubahan sosial ekonomi masyarakat di kampung tematik.

\subsubsection{Data Sekunder}

Teknik pengumpulan data sekunder digunakan untuk mengumpulkan data yang bersifat sekunder. Peneliti membutuhkan data yang didapatkan dari instansi terkait baik berupa dokumen. Selain itu peneliti juga memperoleh data sekunder dari literatur maupun jurnal yang terkait dengan penelitian. Teknik pengumpulan data sekunder nantinya digunakan untuk mendapatkan data terkait sejarah kawasan di kampung tematik dan aksesibilitas didukung oleh transportasi publik di Kota Surakarta.

\subsection{VARIABEL PENELITIAN}

Variabel dalam penelitian ini terbagi menjadi 4, yaitu atraksi wisata berupa kebudayaan, tersedia fasilitas pendukung wisata, membawa perubahan sosial ekonomi masyarakat, dan aksesibilitas yang didukung oleh transportasi publik. Indikator penelitian yang diambil disesuaikan dengan ciri khas kampung tematik. Variabel penelitian yang dihasilkan dapat dilihat pada Tabel 1. 
Tabel 1. Variabel Penelitian

\begin{tabular}{|c|c|c|}
\hline Variabel & Definisi & Indikator \\
\hline $\begin{array}{l}\text { atraksi wisata berupa } \\
\text { kebudayaan }\end{array}$ & $\begin{array}{l}\text { atraksi yang melibatkan budaya } \\
\text { harus menawarkan keberagaman, } \\
\text { keberagaman dapat } \\
\text { mempertahankan dan menggali ciri } \\
\text { khas daerah }\end{array}$ & $\begin{array}{l}\text { fasilitas budaya yang dimanfaatkan masyarakat } \\
\text { event dan festival budaya yang } \\
\text { diselenggarakan masyarakat } \\
\text { sejarah kawasan, } \\
\text { monumen }\end{array}$ \\
\hline & & $\begin{array}{l}\text { kesenian } \\
\text { Kehidupan masyarakatnya. }\end{array}$ \\
\hline $\begin{array}{l}\text { fasilitas pendukung } \\
\text { wisata }\end{array}$ & $\begin{array}{l}\text { Fasilitas pendukung ini berfungsi } \\
\text { untuk memberikan kenyamanan } \\
\text { bagi pengunjung dalam mengakses } \\
\text { elemen primer. }\end{array}$ & $\begin{array}{l}\text { akomodasi yang disediakan masarakat } \\
\text { tempat makan yang disediakan masyarakat } \\
\text { tempat makan yang disediakan masyarakat }\end{array}$ \\
\hline $\begin{array}{l}\text { perubahan sosial } \\
\text { ekonomi masyarakat }\end{array}$ & $\begin{array}{l}\text { Sebagai kampung tematik, maka } \\
\text { harus dapat mengangkat potensi } \\
\text { sosial dan ekonomi masyarakat } \\
\text { setempat (pemberdayaan) }\end{array}$ & $\begin{array}{l}\text { membuka lapangan pekerjaan baru } \\
\text { meningkatkan Pendapatan masyarakat } \\
\text { kontak langsung antara wisatawan dan } \\
\text { pengunjung }\end{array}$ \\
\hline $\begin{array}{l}\text { aksesibilitas yang } \\
\text { didukung oleh } \\
\text { transportasi publik }\end{array}$ & $\begin{array}{l}\text { ukuran kemudahan lokasi untuk } \\
\text { dijangkau dari lokasi lainnya } \\
\text { melalui sistem transportasi }\end{array}$ & $\begin{array}{l}\text { aksesibilitas yang didukung oleh transportasi } \\
\text { publik }\end{array}$ \\
\hline
\end{tabular}

\subsection{METODE ANALISIS}

Penelitian ini menggunakan metode kuantitatif, dengan pendekatan secara deduktif. Peneliti mengumpulkan teori-teori yang kemudian diuji di lapangan. Analisis yang digunakan dalam penelitian ini adalah analisis skoring. Analisis skoring digunakan untuk memberikan skor kepada setiap indikator, subvariabel, dan variabel penelitian. Sebuah indikator, subvariabel, dan variabel penelitian akan mendapatkan skor 1 jika sesuai dan skor 0 jika tidak sesuai. Untuk lebih jelasnya, berikut merupakan tahapan dalam melakukan analisis skoring:

\subsubsection{Analisis Skoring Variabel}

Analisis skoring variabel dilakukan dengan langkah-langkah yang dipaparkan pada Tabel 2.

Tabel 2. Analisis Skoring Variabel pada Masing - Masing Kampung Tematik

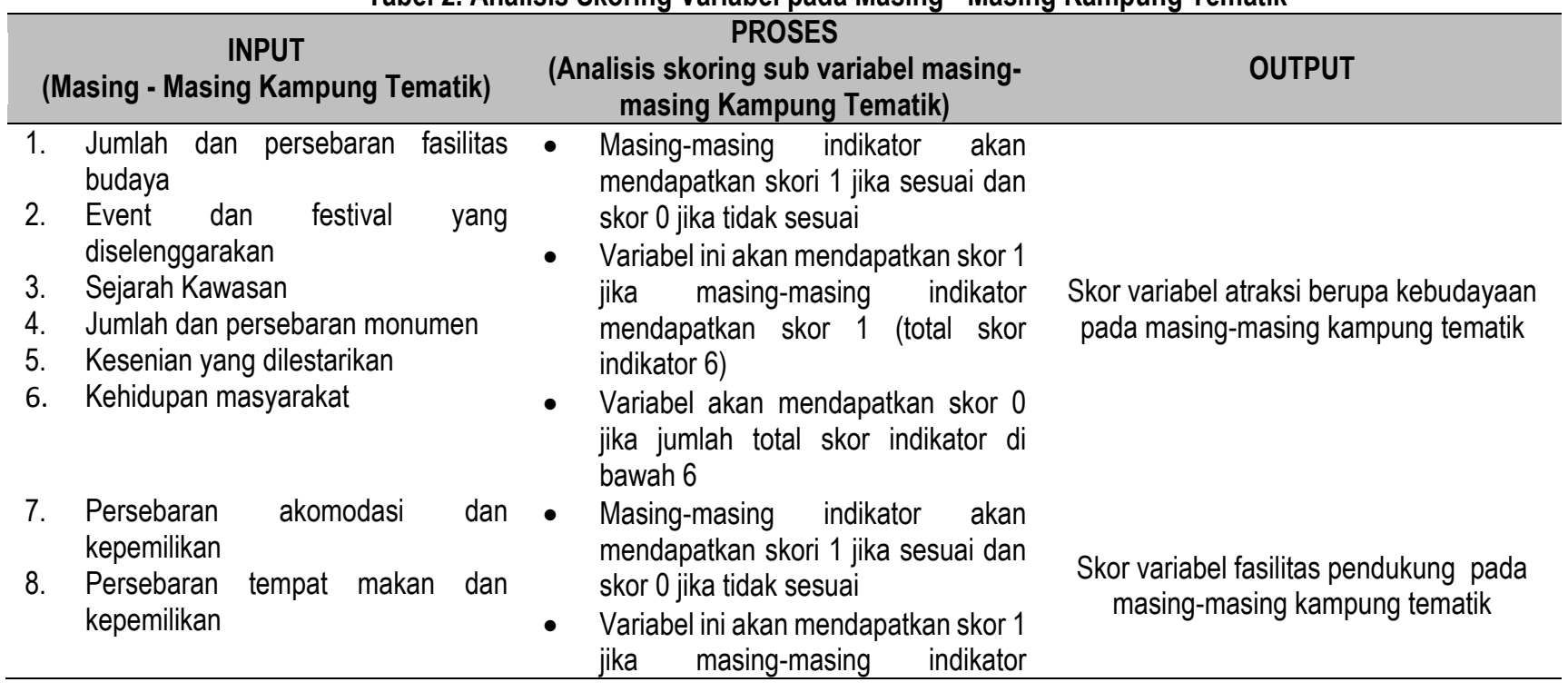




\begin{tabular}{|c|c|c|}
\hline $\begin{array}{c}\text { INPUT } \\
\text { (Masing - Masing Kampung Tematik) }\end{array}$ & $\begin{array}{c}\text { PROSES } \\
\text { (Analisis skoring sub variabel masing- } \\
\text { masing Kampung Tematik) }\end{array}$ & OUTPUT \\
\hline $\begin{array}{l}\text { 9. Persebaran tempat belanja dan } \\
\text { kepemilikan }\end{array}$ & $\begin{array}{l}\text { mendapatkan skor } 1 \text { (total skor } \\
\text { indikator } 3 \text { ) } \\
\text { - Variabel akan mendapatkan skor } 0 \\
\text { jika jumlah total skor indikator di } \\
\text { bawah } 3 \text {. }\end{array}$ & \\
\hline 10. Lapangan pekerjaan baru & - Masing-masing indikator akan & \\
\hline $\begin{array}{l}\text { 11. Peningkatan pendapatan } \\
\text { masyarakat }\end{array}$ & $\begin{array}{l}\text { mendapatkan skori } 1 \text { jika sesuai dan } \\
\text { skor } 0 \text { jika tidak sesuai }\end{array}$ & \\
\hline $\begin{array}{l}\text { 12. Keterlibatan masyarakat dalam } \\
\text { atraksi }\end{array}$ & $\begin{array}{l}\text { - Variabel ini akan mendapatkan skor } 1 \\
\text { jika masing-masing indikator } \\
\text { mendapatkan skor } 1 \text { (total skor } \\
\text { indikator 3) } \\
\text { - Variabel akan mendapatkan skor } 0 \\
\text { jika jumlah total skor indikator di } \\
\text { bawah 3. }\end{array}$ & $\begin{array}{l}\text { Skor variabel perubahan sosial ekonomi } \\
\text { pada masing-masing kampung tematik }\end{array}$ \\
\hline 13. Rute/trayek moda transportasi umum & $\begin{array}{l}\text { - Variabel ini akan mendapatkan skor } 1 \\
\text { jika skor indikator } 1 \\
\text { - Variabel ini akan mendapatkan skor } 0 \\
\text { jika skor indikator } 0\end{array}$ & $\begin{array}{l}\text { Skor variabel fasilitas pendukung pada } \\
\text { masing-masing kampung tematik }\end{array}$ \\
\hline
\end{tabular}

Strategi yang digunakan untuk mengatasi bias dalam penelitian ini, yaitu:

a) Wawancara yang diperkuat dengan observasi dan data sekunder

Responden yang dipilih untuk wawancara dalam penelitian ini adalah ketua paguyuban kampung tematik. Ketua paguyuban merupakan tokoh yang berperan di dalam pengembangan kampung tematik dan mengerti seluk beluk terkait kampung tematik, dengan demikian hasil wawancara dianggap sebagai data yang kebenarannya dapat dibuktikan. Wawancara yang dilakukan kemudian diperkuat dengan observasi di lapangan dan data sekunder, sehingga hasil yang diperoleh tidak hanya berasal dari satu sumber saja.

b) Indikator penelitian

Indikator penelitian yang digunakan dalam penelitian ini merupakan hasil dari sintesa teori terkait urban tourism dan kampung tematik, sehingga dalam pemilihan indikator untuk skor 1 dan 0 tidak hanya dengan intuisi penulis. Indikator penelitian dalam penelitian ini dapat dilihat pada Tabel 3.

Tabel 3. Parameter dan Indikator penelitian

\begin{tabular}{lll}
\hline \multirow{2}{*}{ Parameter } & \multicolumn{1}{c}{ Indikator } \\
\cline { 2 - 3 } & \multicolumn{1}{c}{$\begin{array}{c}\text { Sesuai } \\
\text { (diberi skor 1) }\end{array}$} & \multicolumn{1}{c}{$\begin{array}{c}\text { Tidak Sesuai } \\
\text { (diberi skor 0) }\end{array}$} \\
\hline $\begin{array}{l}\text { Adanya fasilitas budaya yang dikelola oleh } \\
\text { masyarakat }\end{array}$ & $\begin{array}{l}\text { Jika memiliki fasilitas budaya yang } \\
\text { Terselenggaranya event dan festival budaya oleh } \\
\text { masyarakat }\end{array}$ & $\begin{array}{l}\text { dika tidak memiliki fasilitas budaya } \\
\text { jimang dimanfaatkan masyarakat }\end{array}$ \\
& $\begin{array}{l}\text { Jika memiliki event dan festival } \\
\text { budaya yang melibatkan }\end{array}$ & $\begin{array}{l}\text { Jika tidak memiliki event dan } \\
\text { festival budaya yang melibatkan }\end{array}$ \\
Sejarah kawasan & masyarakat & masyarakat \\
& Jika memiliki Sejarah kawasan & Jika tidak memiliki Sejarah kawasan \\
& yang berhubungan dengan elemen & yang berhubungan dengan elemen \\
Adanya Monumen & primer utama Kota Surakarta & primer utama Kota Surakarta \\
Adanya kesenian yang dilestarikan oleh masyarakat & Jika Ada Monumen & Jika tidak Ada Monumen \\
& Jika ada kesenian yang dilestarikan & Jika tidak ada kesenian yang \\
& deh masyarakat & dilestarikan oleh masyarakat \\
\hline
\end{tabular}




\begin{tabular}{|c|c|c|}
\hline \multirow[b]{2}{*}{ Parameter } & \multicolumn{2}{|c|}{ Indikator } \\
\hline & $\begin{array}{c}\text { Sesuai } \\
\text { (diberi skor 1) }\end{array}$ & $\begin{array}{l}\text { Tidak Sesuai } \\
\text { (diberi skor 0) }\end{array}$ \\
\hline Adanya kehidupan masyarakat yang dijadikan atraksi & $\begin{array}{l}\text { Jika ada kehidupan masyarakat } \\
\text { digunakan sebagai atraksi. }\end{array}$ & $\begin{array}{l}\text { Jika tidak ada kehidupan } \\
\text { masyarakat digunakan sebagai } \\
\text { atraksi. }\end{array}$ \\
\hline $\begin{array}{l}\text { Ketersediaan akomodasi yang disediakan oleh } \\
\text { masyarakat }\end{array}$ & $\begin{array}{l}\text { Jika tersedia akomodasi yang } \\
\text { disediakan oleh masyarakat }\end{array}$ & $\begin{array}{l}\text { Jika tidak tersedia akomodasi yang } \\
\text { disediakan oleh masyarakat }\end{array}$ \\
\hline $\begin{array}{l}\text { Ketersediaan warung makan yang disediakan oleh } \\
\text { masyarakat }\end{array}$ & $\begin{array}{l}\text { Jika tersedia rumah makan yang } \\
\text { disediakan oleh masyarakat }\end{array}$ & $\begin{array}{l}\text { Jika tersedia rumah makan yang } \\
\text { disediakan oleh masyarakat }\end{array}$ \\
\hline $\begin{array}{l}\text { Ketersediaan tempat berbelanja yang disediakan oleh } \\
\text { masyarakat }\end{array}$ & $\begin{array}{l}\text { Jika tersedia tempat berbelanja } \\
\text { yang disediakan oleh masyarakat }\end{array}$ & $\begin{array}{l}\text { Jika tersedia tempat berbelanja } \\
\text { yang disediakan oleh masyarakat }\end{array}$ \\
\hline Membuka lapangan pekerjaan baru & $\begin{array}{l}\text { Jika dapat membuka lapangan } \\
\text { pekerjaan baru }\end{array}$ & $\begin{array}{l}\text { Jika tidak dapat membuka lapangan } \\
\text { pekerjaan baru }\end{array}$ \\
\hline Meningkatkan pendapatan masyarakat & $\begin{array}{l}\text { Jika dapat meningkatkan } \\
\text { pendapatan masyarakat }\end{array}$ & $\begin{array}{l}\text { Jika tidak dapat meningkatkan } \\
\text { pendapatan masyarakat }\end{array}$ \\
\hline Melibatkan masyarakat dalam atraksi wisata & $\begin{array}{l}\text { Jika masyarakat dilibatkan dalam } \\
\text { atraksi wisata }\end{array}$ & $\begin{array}{l}\text { Jika masyarakat tidak dilibatkan } \\
\text { dalam atraksi wisata }\end{array}$ \\
\hline $\begin{array}{l}\text { Terjangkau moda transportasi publik yang melewati } \\
\text { semua atraksi wisata urban tourism }\end{array}$ & $\begin{array}{l}\text { Jika kampung tematik terbuffer dan } \\
\text { terjangkau dengan berjalan kaki } \\
\text { dengan jarak } 0-400 \text { meter }\end{array}$ & $\begin{array}{l}\text { Jika kampung tematik terbuffer dan } \\
\text { terjangkau dengan berjalan kaki } \\
\text { dengan jarak lebih dari } 400 \text { meter }\end{array}$ \\
\hline
\end{tabular}

c) Analisis

Analisis penelitian dilakukan dengan kaku, kaku di sini maksudnya jika ada satu indikator saja yang tidak sesuai (mendapatkan skor 0) maka dalam satu variabel tersebut juga dianggap tidak sesuai. Peneliti tidak membagi kesesuaian berdasarkan kelas atau interval, hanya sesuai atau tidak sesuai. Hal tersebut dikarenakan indikator adalah syarat kesesuaian.

\subsubsection{Analisis Kesesuaian Kampung Tematik di Kota Surakarta sebagai elemen primer dalam Konsep Urban Tourism.}

Nilai variabel yang ada pada Tabel 3 nantinya akan digunakan untuk analisis ini. Kampung tematik akan sesuai jika mendapatkan nilai total variabel maksimal sesuai jumlah variabel penelitian, yakni 4. Jika ada kampung tematik yang memiliki nilai total variabel kurang dari 4 berarti tidak sesuai. Setelah diketahui nilai kesesuaian pada masing-masing kampung tematik, kemudian secara keseluruhan dilakukan presentasi kesesuaian Kampung Tematik di Kota Surakarta yang sesuai dengan elemen primer Urban Tourism.

\section{HASIL DAN PEMBAHASAN}

Pada tahun 2018 Kota Surakarta mengembangkan konsep pariwisata Urban Tourism dengan Kampung Tematik sebagai elemen primernya. Terdapat 6 kampung tematik di Kota Surakarta, yaitu Joho Kampoeng Hepi, Kampung Batik Laweyan, Kampung Blangkon Petrojayan, Kampung Sayur Mojosongo, Kampung Batik Kauman, dan Jayengan Kampoeng Permata..

\subsection{IDENTIFIKASI KARAKTERISTIK KESESUAIAN KAMPUNG TEMATIK}

Karakteristik elemen primer urban tourism di Kampung Tematik Kota Surakarta meliputi atraksi berupa kebudayaan, fasilitas pendukung, perubahan sosial ekonomi masyarakat, dan aksesibiltas. Dari ke-4 komponen tersebut, masing-masing memiliki aspek penting di bawahnya.

\subsubsection{Atraksi Berupa Kebudayaan}

Komponen atraksi berupa kebudayaan memiliki 6 aspek sebagai pengukur keberagaman atraksi. Berdasarkan hasil analisis kampung tematik yang mendapatkan nilai 6 (sesuai) sebesar $33 \%$. Hanya 2 kampung tematik yang mendapatkan nilai sesuai, yakni Kampung Batik Kauman dan Kampung Batik Laweyan. Sedangkan yang mendapatkan nilai kurang dari 6 
sebesar 67\% terdiri dari 4 kampung tematik, yaitu Joho Kampoeng Hepi, Kampung Blangkon Petrojayan, Kampung Sayur Mojosongo, dan Jayengan Kampoeng Permata. Untuk menjelaskan hasil tersebut dapat dilihat pada Tabel 4.

Tabel 4. Nilai Kesesuaian Variabel Atraksi yang Melibatkan Kebudayaan

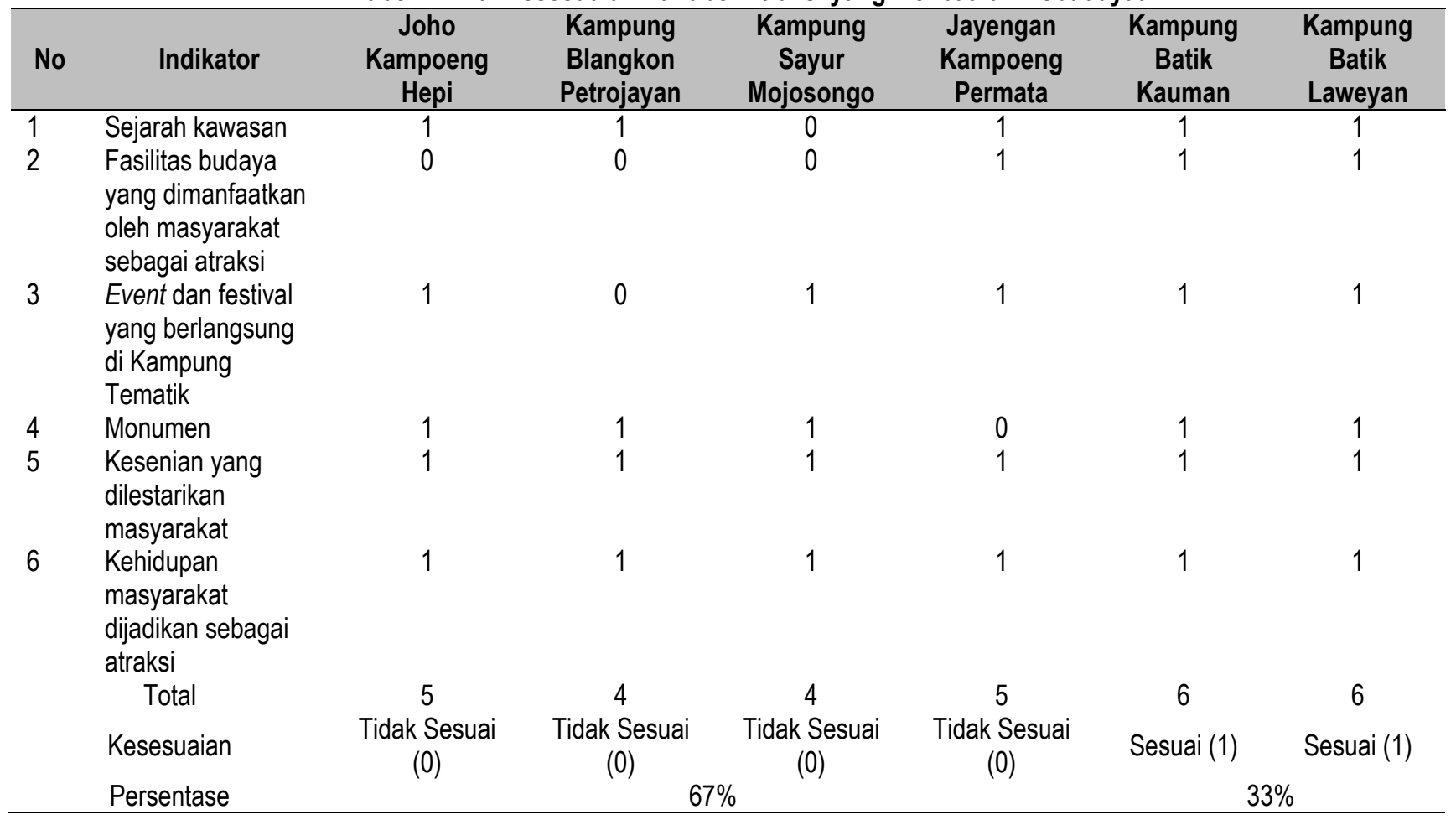

Dengan demikian atraksi wisata di Kampung Tematik belum dapat menawarkan keberagaman kebudayaan, dikarenakan hanya sebesar $33 \%$ dari Kampung Tematik di Kota Surakarta yang sudah memiliki semua komponen atraksi wisata berupa kebudayaan dalam konsep Urban Tourism di Kampung Tematik. Hal ini tidak sesuai dengan peraturan UU nomor 10 tahun 2009 tentang kepariwisataan disebutkan bahwa atraksi yang melibatkan budaya harus menawarkan keberagaman. Keberagaman atraksi wisata yang ditawarkan dapat mempertahankan dan menggali ciri khas daerah sehingga mampu mempertahankan kepribadian dengan nilai luhur bangsa dari pengaruh dan tantangan dari luar (Monariyanti, 2015).

Salah satu tujuan diadakannya program urban tourism adalah untuk menyelesaikan permasalahan stagnasi obyek wisata di Kota Surakarta. Atraksi yang berupa kebudayaan merupakan komponen pokok di dalam elemen primer. Dengan jumlah kesesuaian komponen atraksi berupa kebudayaan sebesar 33\%, hal ini berarti tidak mendukung pariwisata di Kota Surakarta supaya tidak stagnan. Hasil tersebut menunjukkan bahwa masih banyak aspek pada kampung tematik yang belum terpenuhi.

Terdapat tiga kampung tematik yang belum memiliki fasilitas budaya, yakni Joho Kampoeng Hepi, Kampung Blangkon Petrojayan, dan Kampung Sayur Mojosongo. Ketiadaan fasilitas budaya ini disebabkan oleh beberapa faktor, seperti tidak tersedianya lahan, belum memiliki rancangan untuk membuat, dan keterbatasan biaya. Masyarakat di Kampung Blangkon Petrojayan melalui Paguyuban Maju Utomo belum berinisiatif dan proaktif dalam menyelenggarakan event dan festival budaya. Jayengan Kampoeng Permata adalah satu-satunya kampung tematik yang belum memiliki monumen. Rencana pembangunan monumen ini akan terlaksana pada tahun 2020, saat ini baru pada tahap perencanaan dan perancangan. Sehingga ketiga aspek tersebut tidak sesuai pada Gambar 1.

\subsubsection{Fasilitas Pendukung}

Berdasarkan hasil analisis didapatkan bahwa komponen ini mendapatkan hasil kesesuaian sebesar $50 \%$. Kondisi ini tidak sesuai dengan teori yang dikemukakan oleh Page (2002) bahwa elemen primer dalam urban tourism harus membuat nyaman baik pengunjung maupun penduduk secara bersamaan, dan memiliki pelayanan dan fasilitas yang beragam. Keadaan ini 
mengakibatkan kenyamanan wisatawan berkurang ketika mengakses elemen primer. Seperti pada teori di atas bahwa kenyamanan pengunjung dapat dilihat dengan lengkapnya fasilitas pendukung yang berada di kampung tematik.

Ketidaksesuaian ini dikarenakan ada 3 kampung tematik yang masyarakatnya belum menyediakan aspek akomodasi. Kampung tematik yang belum menyediakan akomodasi adalah Joho Kampoeng Hepi, Kampung Blangkon Petrojayan, dan Kampung Sayur Mojosongo. Hanya masyarakat yang ada pada Jayengan Kampoeng Permata, Kampung Batik Kauman, dan Kampung Batik Laweyan yang menyediakan akomodasi untuk masyarakat. Jenis akomodasi yang disediakan oleh masyarakat di 3 kampung tematik tersebut adalah hotel dan home stay. Sehingga aspek akomodasi tidak sesuai pada Gambar 1. Selain itu belum disediakannya akomodasi oleh masyarakat menunjukan bahwa masyarakat di Joho Kampoeng Hepi, Kampung Blangkon Petrojayan, dan Kampung Sayur Mojosongo belum proaktif dalam menyediakan akomodasi.

Aspek rumah makan dan tempat belanja sudah disediakan oleh masyarakat di seluruh Kampung Tematik dengan jumlah yang berbeda-beda. Jayengan Kampoeng Permata memiliki jumlah tempat makan terbanyak sedangkan Kampung Sayur Mojosongo memiliki jumlah tersedikit. Tidak hanya disediakan oleh masyarakat, beberapa tempat makan yang ada di Kampung tematik merupakan milik pihak ke-3 atau bukan masyarakat di Kampung Tematik. Hanya Kampung Batik Laweyan yang kepemilikan atas tempat makannya didominasi oleh pihak ke-3, untuk kampung lainnya masih didominasi kepemilikannya oleh masyarakat. Sedangkan pada aspek tempat belanja di semua kampung tematik kepemilikannya di dominasi oleh masyarakat. Untuk lebih jelasnya dapat dilihat pada Tabel 5.

Tabel 5. Nilai Kesesuaian Variabel Fasilitas Pendukung

\begin{tabular}{|c|c|c|c|c|c|c|c|}
\hline No & Indikator & $\begin{array}{c}\text { Joho } \\
\text { Kampoeng } \\
\text { Hepi }\end{array}$ & $\begin{array}{l}\text { Kampung } \\
\text { Blangkon } \\
\text { Petrojayan }\end{array}$ & $\begin{array}{l}\text { Kampung } \\
\text { Sayur } \\
\text { Mojosongo }\end{array}$ & $\begin{array}{c}\text { Jayengan } \\
\text { Kampoeng } \\
\text { Permata }\end{array}$ & $\begin{array}{c}\text { Kampung } \\
\text { Batik } \\
\text { Kauman }\end{array}$ & $\begin{array}{l}\text { Kampung } \\
\text { Batik } \\
\text { Laweyan }\end{array}$ \\
\hline 1 & $\begin{array}{l}\text { Ketersediaan akomodasi yang } \\
\text { disediakan oleh masyarakat }\end{array}$ & 0 & 0 & 0 & 1 & 1 & 1 \\
\hline 2 & $\begin{array}{l}\text { Ketersediaan rumah makan yang } \\
\text { disediakan oleh masyarakat }\end{array}$ & 1 & 1 & 1 & 1 & 1 & 1 \\
\hline \multirow[t]{4}{*}{3} & $\begin{array}{l}\text { Ketersediaan tempat belanja yang } \\
\text { disediakanoleh masyarakat }\end{array}$ & 1 & 1 & 1 & 1 & 1 & 1 \\
\hline & Total & 2 & 2 & 2 & 3 & 3 & 3 \\
\hline & Kesesuaian & $\begin{array}{c}\text { Tidak } \\
\text { Sesuai (0) }\end{array}$ & $\begin{array}{c}\text { Tidak } \\
\text { Sesuai (0) }\end{array}$ & $\begin{array}{c}\text { Tidak } \\
\text { Sesuai (0) }\end{array}$ & Sesuai (1) & Sesuai (1) & Sesuai (1) \\
\hline & Persentase & & $50 \%$ & & & $50 \%$ & \\
\hline
\end{tabular}

\subsubsection{Perubahan Sosial Ekonomi Masyarakat}

Dari analisis yang sudah dilakukan didapatkan hasil bahwa elemen primer dapat membawa perubahan sosial ekonomi di seluruh kampung tematik. Perubahan ini dikarenakan adanya atraksi wisata di kampung tematik, dan juga kesadaran masyarakat dalam menyediakan fasilitas pendukung. Ke dua komponen tersebut mendatangkan keuntungan berupa peningkatan pendapatan masyarakat serta membuka lapangan pekerjaan baru. Hal tersebut dapat dilihat dari jumlah skor di seluruh kampung tematik yang mendapatkan nilai total 3 . Hasil tersebut sesuai dengan tujuan kampung tematik berdasarkan Ujianto, Zahro, \& Maringka, (2018) salah satunya mengatakan bahwa kampung tematik harus dapat mengangkat potensi sosial dan ekonomi masyarakat setempat (pemberdayaan).

Lapangan pekerjaan baru yang terbuka di kampung tematik jenisnya bervariasi. Pekerjaan tersebut berhubungan erat dengan pariwisata, khususnya terkait dengan tema dari kampung tematik. Hasil analisis menunjukan bahwa masyarakat di kampung tematik sudah merasakan peningkatan pendapatan sebagai dampak dari pariwisata. Dari 30 responden yang ada di masing-masing kampung tematik, diketahui bahwa jumlah persentase masyarakat yang merasakan dampak ini berbedabeda. Kampung Batik Laweyan memiliki jumlah persentase masyarakat yang terdampak paling besar, sedangkan Joho Kampoeng Hepi memiliki jumlah persentase masyarakat yang merasakan dampak peningkatan pendapatan paling sedikit. Sesuai dengan teori dari Page (2002) elemen primer dalam urban tourism dapat menciptakan industri baru, sehingga dapat membuka lapangan pekerjaan baru, meningkatkan pendapatan masyarakat, serta meningkatkan standar hidup. 
Berdasarkan hasil analisis pada aspek kontak langsung wisatawan dengan penduduk setempat sudah dapat melibatkan masyarakat dalam atraksi. Dapat dilihat pada komponen 4.1.1 atraksi berupa kebudayaan, masyarakat berperan di dalam aspek-aspek pada komponen tersebut. Keterlibatan masyarakat tidak hanya sekedar pada atraksi wisatanya tetapi juga pada fasilitas pendukung yang disediakan, dapat dilihat pada komponen 4.1.2 fasilitas pendukung. Untuk lebih jelasnya nilai kesesuaian variabel perubahan sosial ekonomi masyarakat dapat dilihat pada Tabel 6.

Tabel 6. Nilai Kesesuaian Variabel Perubahan Sosial Ekonomi Masyarakat

\begin{tabular}{|c|c|c|c|c|c|c|c|}
\hline No & Indikator & $\begin{array}{c}\text { Joho } \\
\text { Kampoeng } \\
\text { Hepi }\end{array}$ & $\begin{array}{l}\text { Kampung } \\
\text { Blangkon } \\
\text { Petrojayan }\end{array}$ & $\begin{array}{l}\text { Kampung } \\
\text { Sayur } \\
\text { Mojosongo }\end{array}$ & $\begin{array}{l}\text { Jayengan } \\
\text { Kampoeng } \\
\text { Permata }\end{array}$ & $\begin{array}{l}\text { Kampung } \\
\text { Batik } \\
\text { Kauman }\end{array}$ & $\begin{array}{l}\text { Kampung } \\
\text { Batik } \\
\text { Laweyan }\end{array}$ \\
\hline 1 & \multirow{2}{*}{$\begin{array}{l}\text { Membuka lapangan pekerjaan baru } \\
\text { Meningkatkan pendapatan } \\
\text { masyarakat }\end{array}$} & 1 & 1 & 1 & 1 & 1 & 1 \\
\hline 2 & & 1 & 1 & 1 & 1 & 1 & 1 \\
\hline \multirow[t]{2}{*}{3} & $\begin{array}{l}\text { Melibatkan masyarakat dalam } \\
\text { atraksi }\end{array}$ & 1 & 1 & 1 & 1 & 1 & 1 \\
\hline & $\begin{array}{l}\text { Total } \\
\text { Kesesuaian } \\
\text { Persentase }\end{array}$ & $\begin{array}{c}3 \\
\text { Sesuai (1) }\end{array}$ & $\begin{array}{c}3 \\
\text { Sesuai (1) }\end{array}$ & $\begin{array}{c}3 \\
\text { Sesuai (1) } \\
100 \%\end{array}$ & $\begin{array}{c}3 \\
\text { Sesuai (1) }\end{array}$ & $\begin{array}{c}3 \\
\text { Sesuai (1) }\end{array}$ & $\begin{array}{c}3 \\
\text { Sesuai (1) }\end{array}$ \\
\hline
\end{tabular}

\subsubsection{Aksesibilitas}

Aksesibilitas adalah ukuran kemudahan lokasi untuk dijangkau dari lokasi lainnya melalui sistem transportasi (Muta'ali, 2015). Dalam urban tourism, aksesibilitas harus didukung oleh transportasi publik. Transportasi publik di Kota Surakarta menggunakan Batik Solo Trans (BST) dan angkutan kota (sekarang sudah berganti menjadi BST). Menurut SNI 03-17332004, untuk mengukur komponen aksesibilitas di Kampung Tematik dilakukan dengan cara membuffer sejauh 400m dari jalan yang dilewati oleh koridor BST. Analisis dilakukan menggunakan software GIS, sehingga didapatkan hasil bahwa semua kampung tematik terbuffer oleh koridor BST.

Seperti yang dikatakan oleh Edwards (2008) kunci elemen primer adalah bahwa kawasan dengan mudah diakses terutama oleh bandara dan transportasi publik yang lain. Dengan demikian, meskipun hanya 1 koridor yang melewati sudah dianggap sesuai oleh peneliti.

Tabel 7. Nilai Kesesuaian Variabel Aksesibilitas

\begin{tabular}{|c|c|c|c|c|c|c|c|}
\hline No & Indikator & $\begin{array}{c}\text { Joho } \\
\text { Kampoeng } \\
\text { Hepi }\end{array}$ & $\begin{array}{l}\text { Kampung } \\
\text { Blangkon } \\
\text { Petrojayan }\end{array}$ & $\begin{array}{l}\text { Kampung } \\
\text { Sayur } \\
\text { Mojosongo }\end{array}$ & $\begin{array}{l}\text { Jayengan } \\
\text { Kampoeng } \\
\text { Permata }\end{array}$ & $\begin{array}{l}\text { Kampung } \\
\text { Batik } \\
\text { Kauman }\end{array}$ & $\begin{array}{l}\text { Kampung } \\
\text { Batik } \\
\text { Laweyan }\end{array}$ \\
\hline \multirow[t]{3}{*}{1} & $\begin{array}{l}\text { Aksesibilitas yang } \\
\text { didukung oleh } \\
\text { transportasi publik }\end{array}$ & $\begin{array}{c}1 \\
\text { (Koridor } 2 \text { dan } \\
12)\end{array}$ & $\begin{array}{c}1 \\
\text { (Koridor } 3,5, \\
7,9,11 \text {, dan } \\
13 \text { ) }\end{array}$ & $\begin{array}{c}1 \\
\text { (Koridor 4) }\end{array}$ & $\begin{array}{c}1 \\
\text { (Koridor } 1,3 \\
5,7,9,13 \text {, dan } \\
14)\end{array}$ & $\begin{array}{c}1 \\
\text { (Koridor 1, 3, } \\
6,7,9,10, \\
11,12,13, \\
14 \text {, dan 15) }\end{array}$ & $\begin{array}{c}1 \\
\text { (Koridor 3, 7, } \\
\text { 12, dan 14) }\end{array}$ \\
\hline & & 1 & 1 & 1 & 1 & 1 & 1 \\
\hline & $\begin{array}{l}\text { Total } \\
\text { Kesesuaian } \\
\text { Persentase }\end{array}$ & Sesuai (1) & Sesuai (1) & $\begin{array}{l}\text { Sesuai (1) } \\
10\end{array}$ & Sesuai (1) & Sesuai (1) & Sesuai (1) \\
\hline
\end{tabular}

Kampung Batik Kauman merupakan yang paling banyak dijangkau oleh koridor BST, sedangkan Kampung Sayur Mojosongo merupakan yang paling sedikit. Jika dilihat lebih lanjut BST cenderung memiliki asal dan tujuan ke Terminal Kartasura dan Bandara Adi Sumarmo. Sehingga persinggahannya lebih banyak ke tempat komersil dan area CBD, letak Kampung Batik Kauman berada pada daerah pusat kota sehingga lebih cenderung banyak dilewati koridor BST dibandingkan kampung yang lainnya. Kesesuaian variabel aksesibilitas dapat dilihat pada Tabel 7. 


\subsection{KESESUAIAN KAMPUNG TEMATIK DI KOTA SURAKARTA SEBAGAI ELEMEN PRIMER URBAN TOURISM}

Kampung tematik di Kota Surakarta berperan sebagai elemen primer di dalam konsep urban tourism yang diharapkan dapat menarik masyarakat untuk berwisata ke Kota Surakarta. Kampung tematik di Kota Surakarta memiliki tema yang beragam, di mana tema atau topik tersebut merupakan representasi dari aktivitas keseharian masyarakat yang diangkat menjadi atraksi wisata. Komponen yang digunakan untuk mengidentifikasi karakteristik kampung tematik sebagai elemen primer ada 4, yaitu atraksi yang melibatkan kebudayaan, fasilitas pendukung, perubahan sosial ekonomi masyarakat, dan aksesibilitas.

Didapatkan hasil bahwa kampung tematik di Kota Surakarta hanya memperoleh persentase nilai kesesuaian sebesar 33\%. Nilai ini diperoleh karena Kampung Batik Kauman dan Kampung Batik Laweyan mendapatkan nilai total variabel 4. Sedangkan 4 kampung tematik lainnya yang mendapatkan nilai variabel kurang dari 4, yaitu Joho Kampoeng Hepi, Kampung Blangkon Petrojayan, Kampung Sayur Mojosongo, dan Jayengan Kampoeng Permata. Hal ini dikarenakan masih banyak aspek-aspek yang belum dapat dilengkapi oleh ke-4 kampung tematik tersebut. Apek itu di antaranya fasilitas budaya yang dimanfaatkan oleh masyarakat, monumen, event dan fasilitas budaya serta akomodasi. Apabila 4 aspek tersebut dapat dipenuhi oleh kampung tematik, maka akan memperoleh nilai variabel yang maksimal dan sesuai sebagai elemen primer dalam urban tourism.

Kesesuaian yang dicapai oleh kampung tematik sebesar 33\% membuktikan bahwa pariwisata di Kota Surakarta memang masih mengalami stagnasi. Dampak yang ditimbulkan dari stagnannya obyek wisata ini adalah masih menurunnya jumlah wisatawan yang berkunjung ke Kota Surakarta. Berdasarkan Badan Pusat Statistika (BPS) Kota Surakarta jumlah pengunjung berdasarkan tingkat penghunian kamar hotel di Kota Surakarta dari tahun 2018 ke tahun 2019 mengalami penurunan sebesar $7.85 \%$. Untuk lebih jelasnya, dapat dilihat pada Tabel 8.

Tabel 8. Nilai Kesesuaian Kampung Tematik di Kota Surakarta sebagai Elemen Primer dalam Konsep Urban Tourism

\begin{tabular}{|c|c|c|c|c|c|c|c|}
\hline No & Variabel & $\begin{array}{c}\text { Joho } \\
\text { Kampoeng } \\
\text { Hepi }\end{array}$ & $\begin{array}{l}\text { Kampung } \\
\text { Blangkon } \\
\text { Petrojayan }\end{array}$ & $\begin{array}{l}\text { Kampung } \\
\text { Sayur } \\
\text { Mojosongo }\end{array}$ & $\begin{array}{c}\text { Jayengan } \\
\text { Kampoeng } \\
\text { Permata }\end{array}$ & $\begin{array}{c}\text { Kampung } \\
\text { Batik } \\
\text { Kauman }\end{array}$ & $\begin{array}{l}\text { Kampung } \\
\text { Batik } \\
\text { Laweyan }\end{array}$ \\
\hline 1 & $\begin{array}{l}\text { Atraksi yang melibatkan } \\
\text { kebudayaan }\end{array}$ & 0 & 0 & 0 & 0 & 1 & 1 \\
\hline 2 & Fasilitas pendukung & 0 & 0 & 0 & 1 & 1 & 1 \\
\hline 3 & $\begin{array}{l}\text { Perubahan sosial ekonomi } \\
\text { masyarakat }\end{array}$ & 1 & 1 & 1 & 1 & 1 & 1 \\
\hline \multirow[t]{5}{*}{4} & Aksesibilitas & 1 & 1 & 1 & 1 & 1 & 1 \\
\hline & & 2 & 2 & 2 & 3 & 4 & 4 \\
\hline & Total & & & & & & \\
\hline & Kesesuaian & Tidak Sesuai & $\begin{array}{l}\text { Tidak } \\
\text { Sesuai }\end{array}$ & $\begin{array}{l}\text { Tidak } \\
\text { Sesuai }\end{array}$ & $\begin{array}{l}\text { Tidak } \\
\text { Sesuai }\end{array}$ & Sesuai & Sesuai \\
\hline & Persentase & & \multicolumn{2}{|c|}{$67 \%$} & & \multicolumn{2}{|c|}{$33 \%$} \\
\hline
\end{tabular}

\section{KESIMPULAN}

Dalam menentukan kesesuian kampung tematik sebagai elemen primer urban tourism dilakukan identifikasi karakteristik berdasarkan terhadap 4 komponen, yaitu atraksi wisata yang melibatkan kebudayaan, fasilitas pendukung, perubahan sosial ekonomi masyarakat dan aksesibilitas. Kampung tematik di Kota Surakarta sebagai elemen primer di dalam urban tourism memiliki nilai kesesuaian sebesar 33\%. Kampung tematik yang sesuai adalah Kampung Batik Kauman dan Kampung Batik Laweyan sedangkan kampung tematik yang tidak sesuai adalah Joho Kampoeng Hepi, Kampung Blangkon Petrojayan, Kampung Sayur Mojosongo, dan Jayengan Kampoeng Permata. Empat kampung tematik di Kota Surakarta sebagai elemen primer belum dapat memenuhi teori yang terdapat pada Gambar 1, untuk bagian atraksi berupa kebudayaan dan fasilitas pendukung. 
Kesesuaian kampung tematik sebagai elemen primer yang hanya sebesar 33\%, kemudian dibuktikan dengan masih menurunnya jumlah kunjungan wisatawan ke Kota Surakarta menunjukan bahwa kampung tematik sebagai elemen primer belum dapat mendukung urban tourism. Sejatinya tujuan diadakannya urban tourism adalah untuk menghilangkan stagnasi obyek wisata dan meningkatkan jumlah kunjungan wisatawan ke Kota Surakarta.

\section{UCAPAN TERIMA KASIH}

Terima kasih peneliti ucapkan yang pertama kepada Tuhan Yang Maha Esa, atas limpahan berkat dan karuniaNya. Selanjutnya kepada Program Studi Perencanaan Wilayah dan Kota, Fakultas Teknik, Universitas Sebelas Maret atas dukungan yang telah diberikan selama melakukan penelitian hingga dapat dipublikasikan. Penelitian ini bagian dari Tugas Akhir yang berjudul Kesesuian Kampung Tematik di Kota Surakarta sebagai Elemen Primer dalam Konsep Urban Tourism.

\section{DAFTAR PUSTAKA}

Aosgi. (2018, Februari 25). Panen Untung Lewat Wisata Kampung, Surakarta.go.id. Diakses dari https://surakarta.go.id/?p=8910

Badan Perencanaan, Penelitian, dan Pengembangan Daerah. (2016). Peraturan Daerah Kota Surakarta Nomor 13 tahun 2016 tentang Rencana Induk Pembangunan Kepariwisataan Daerah (RIPPKADA) tahun 2016-2026. Diakses dari http://jdih.surakarta.go.id/jdihsolo/proses/produkhukum/file/6054_PERDA_NO_13_TAHUN_2016_ver_ttd_GB.pdf

Edwards, D. (2008). Urban Tourism Research: Developing an Agenda, Annals of tourism research, 35(4), 1032-1052, DOI: 10.1016/j.annals.2008.09.002

Garbea, R. V. (2013). Urban Tourism Between Content and Aspiration for Urban Development, Management \& Marketing , 9(1), 193 - 200. Diakses dari https://www.mnmk.ro/documents/2013-01/15-13-1-13.pdf

Inskeep, E. (1991). Tourism Planning-An Integrated Suistainable Approach. New York: Van Nostrand Reinhold.

Kloczko-Gajewska, A. (2014). Can we treat thematic villages as social innovations?, Journal of Central European Green Innovation, 2(3), 49-59. DOI: 10.22004/ag.econ.188135

Monariyanti, N. (2015). Seni Pertunjukan sebagai Atraksi Wisata Budaya di Kecamatan Karimun Kabupaten Karimun Provinsi Kepualaun Riau, Jurnal. Jom FISIP, 2(1), 1-14. Diakses dari https://media.neliti.com/media/publications/32083-ID-seni-pertunjukan-sebagaiatraksi-wisata-budaya-di-kecamatan-karimun-kabupaten-ka.pdf

Muta'ali, L. (2015). Teknik Analisis Regional. Yogyakarta: Badan Penerbit Fakultas Geografi (BPFG) Universitas Gadjah Mada.

Page, S. (2002). Urban Tourism: Evaluating the Tourist's Experiences of Urban Places. The Tourist Experience-a New Approach. London: Contiuum.

Priono, Y. (2012). Identifikasi Produk Pariwisata Kota (Urban Tourism) Kota Pangkalan Bun Sebagai Urban Heritage Tourism, Jurnal Prespektif Arsitektur, 7(2), 72-84. Diakses dari https://e-journal.upr.ac.id/index.php/JTA/article/view/841

Razavi, K., Barta, F. T., \& Amini, E. (2017). The Effective Spatial Qualities on Urban Tourism in Iran Focusing on Social Factors. ICTTE 2017 EDP Sciences, 124. DOI: 10.1051/matecconf/201712406003

Ruetsche, Judith. (2006). Urban Tourism "What Attracts Visitors to Cities?", Extension, 117. Diakses dari https://fyi.extension.wisc.edu/downtowneconomics/files/2012/08/urban-tourism.pdf

SNI 03-1733-2004 Tentang Tata Cara Perencanaan Lingkungan Perumahan di Perkotaan. Diakses dari http://sni.litbang.pu.go.id/index.php?r=/sni/new/sni/detail/id/694

Tamara, A. P., \& Rahdriawan, M. (2018). Kajian Pelaksanaan Konsep Kampung Tematik di Kampung Hidroponik Kelurahan Tanjung Mas Kota Semarang, Jurnal Wilayah dan Lingkungan, 6(1), 40-57. DOI: 10.14710/jwl.6.1.40-57

Ujianto, B. T., Zahro, H. Z., \& Maringka, B. (2018). Kegiatan Perancangan Kampung Belimbing RW 08-09 Kel. Blimbing, Kec. Blimbing, Kota Malang, Jurnal Arsitektur, 2(2), 57-72. Diakses dari http://eprints.itn.ac.id/3029/1/2015-205-3463-1-10-20180724.pdf

UNWTO. (n.d.). Urban Tourism. Diakses dari https://www.unwto.org/urban-tourism

Undang-Undang Nomor $10 \quad$ Tahun 2009 tentang Kepariwisataan. Diakses dari https://jdih.kemenkeu.go.id/fullText/2009/10TAHUN2009UU.HTM

Wicaksono, B. (2018, Maret 5). Dongkrak Sektor Pariwisata, Ini yang Dilakukan Pemkot Solo, Radar Solo Jawa Pos. Diakses dari https://radarsolo.jawapos.com/read/2018/03/05/54469/dongkrak-sektor-pariwisata-ini-yang-dilakukan-pemkot-solo

Widodo, L. (2018, Juni 26). Solo Butuh Platform Pariwisata, Suaramerdeka.com. Diakses dari https://www.suaramerdeka.com/news/baca/97839/e-paper

Widyaiswaratika, T. D. (2016). Pengaruh Creative Tourism terhadap Behavioral Intention dengan Variabel Moderator Motivasi Wisatawan, Repository Indonesia University of Education. Diakses dari http://repository.upi.edu/23233/ 